\title{
School Physics Assistance Learning using the TAI (Team Assisted Individualization) Model: Analysis of Student Evaluation Capabilities
}

\author{
Umi Pratiwi \\ Purworejo Muhammadiyah University, Indonesia \\ umipratiwi@umpwr.ac.id
}

Received: November $30^{\text {th }}, 2019$. Revised: February $4^{\text {th }}, 2020$. Accepted: February $5^{\text {th }}, 2020$

Keywords :

School Assistance; TAI Model;

Evaluation Ability

\begin{abstract}
The ability of prospective teacher students obtained in lectures needs to be developed to be applied in learning in schools. One of them is by applying the TAI learning model. The application of the TAI (Team AssistedIndividualization) learning model is implemented to analyze the student's evaluation ability in the implementation of school assistance and and to add to the experience of students in the real field. This effort was carried out with four stages of TAI namely Teams, Placement Tests, Student Creative, and Teaching Group. At each stage of the TAI model, students provide a description and analysis in the form of activity reports and presentations. The research conducted is a description of collaborating with experimental research, one-shot case study research on students of physics level 5 and data collection techniques with observation and interviews. The results showed that students had the highest ability to evaluate the ability to provide solutions to the obstacles found in partner schools and the lowest ability to find a settlement procedure that was suitable for the scope of the implementation of school assistance.
\end{abstract}

\section{INTRODUCTION}

The quality of education can be seen from the results of learning, namely the ability of students to apply their abilities [1]. Successful learning can also be seen from the ability of students to apply everyday abilities in the real world [2]. Students will always improve their competitiveness to continue to excel. One of the competitive characteristics possessed by students is their activeness in learning, students are directed into active learning [3].Active learning will lead students to more easily communicate and work together in their teams [4]. Learning in higher education cannot be separated from the role of lecturers and students. Students are more demanded for activeness, creativity and the ability to collaborate, especially prospective teacher students [5]. The problem that often occurs is that many students when the learning process depends only on the transfer of knowledge in class. The fact that occurs in our study program that many students when the learning process depends only on the transfer of knowledge in class. When students solve physics problems especially subjects in the field of study programs, their abilities are still low with visible results of the main courses of study programs with low grades.Students do not yet have high awareness about fulfilling the needs in the academic field related to the material 
taught in the lecture room. In addition, a problem that often occurs when the lecture process in the physics education study program at the University of MuhammadiyahPurworejo is that the lecturer does not play his role as a mediator or facilitator.. Lecturers play a passive role when facing passive students, so the two-way learning process does not go well.In addition, several problems that occur in high school for the analysis of student ability, this supports with low classical completeness. Physics material with basic competency in analyzing ability produces low scores. Meanwhile, for basic competency analysis 14.47 or 0.38 of the total existing basic competencies [6].

The learning method used and the focus of students when the learning process also influences learning outcomes and has not increased learning motivation, this is because learning is still teacher-centered [7]. This has an effect on the low student learning outcomes, especially in physics [8]. Physics as a branch of science is the result of organized activities, ideas and concepts about natural phenomena around through scientific processes [9]. Physics is very closely related to natural phenomena causing it is needed in daily life. Therefore to study and understand it requires scientific reasoning and abstract concepts [2]. One of the obstacles faced by prospective physics teachers is not only the understanding of concepts but the involvement of students in learning that is not optimal [10].

The involvement of students, especially prospective physics teachers, is very important as a learning process. Physics education students as physics teacher candidates need a learning experience in the physics learning process to feel interacting with students at school. The involvement of students in the learning process can stimulate activity and motivation. It is important that students get independent learning to conceptualize independent learning and resolve any conflicting problems in learning [11].Students need real experience to be able to solve and analyze problems in the field such as problems related to learning physics and physics practicum.

Prospective physics teachers must have good skills in processing learning to increase motivation and learning outcomes of students. One of the abilities of the prospective physics teacher is the ability to evaluate the learning process that has been carried out by determining the standard criteria specified as a measure of quality [12]. Goodcriteria include two things namely checking criteria which consist of coordinating, detecting, monitoring, and testing [11]. While the second criterion includes the ability to criticize or judge.Another factor influencing student learning outcomes and learning process is laboratory infrastructure to support the implementation of practicum. Practicum is an important part in the physics learning process, which is to improve students' thinking abilities in psychomotor abilities, systematic thinking, objective and creative [13]. Increased competence in learning physics is strongly influenced by the activeness of students and fostering motivation, it requires a learning model that is student-centered, one of which is cooperative learning a learning model that emphasizes the activeness of students to learn together to create meaningful learning or meaningful learning [14]. Cooperative learning allows students to work collaboratively in a small group that has different levels of competence and interact with each other [15].

The TAI type cooperative learning model is suitable to be applied in learning to foster collaboration collaboration with individual work. This learning model allows one group member who has good competency to become an assistant. This assistant is tasked with helping other group members who are less able to carry out their group work [16]. The advantage of the TAI learning model is that students are motivated, have good communication, and cooperative attitudes emerge. While its weaknesses are inadequate learning facilities, the making of instructional media that require a long time, and the critical skills needed when evaluating student performance in groups.

TAI learning model in physics learning material elasticity can increase the activities of students when learning takes place [17], the team asisted individualization (TAI) learning model can improve learning outcomes and produce better learning achievement than conventional learning models [2].The TAI learning model can stimulate students to work in teams and learn to collaborate with other team members to solve problems together.Based on the foregoing the purpose of the study is to apply the TAI learning model in physics assistance learning which is carried out in five high schools in Purworejoregency. 
Physics assistance learning is training in physics education students as candidates for physics teachers to teach school physics practicum subjects. Implementation of physical assistance in it includes designing practicum modules, designing media / tools for practicum, and designing evaluations of practicum implementation such as preparing pre-test and post-test questions. The application of the TAI learning model aims to analyze the ability of studentshigh school students in physics practicum subjects. In learning TAI in this study conducted by practicing in the real world as real teachers in schools, so it is expected that prospective teacher students will get direct experience when interacting with students in partner schools.

\section{METHOD}

This research used descriptive research and collaborates with pre-experimental research with a one-shot case study design. This study was conducted without comparison and also a preliminary test [18]. The purpose of this study is to describe and analyze quantitatively the application of the TAI learning model of physics assistance learning and to determine the ability to evaluate physics education. fourth semester students in physics practicum subjects. Evaluation of learning outcomes follows the steps of the TAI learning model with data collection techniques such as observation and interviews. Observation techniques are used during the learning process of physics assistance to schools with the TAI method and to obtain data on the ability to evaluate students. While interviews and presentations are used to determine the implementation of assistance programs in schools when the program has finished. Analysis of the description data is used to determine the implementation of the TAI learning model in physics education students. Qualitative data analysis techniques consist of three main stages, including: 1) Data Reduction), namely summarizing activities, selecting the main point, and focusing the data on observations in accordance with the focus of the evaluation aspects of the capabilities being studied; 2) Data Display, namely observation data that has been summarized through data reduction activities which are then presented in narrative form; 3) Image Conclusions, namely observational data presented in narrative form and then generalized to get conclusions [15]. This conclusion will represent all data or information from observations of the ability to evaluate with the application of the TAI learning model. Indicator of ability to evaluate [11] can be seen in Table 1.

Table 1. General Indicators of Evaluation Ability

\begin{tabular}{ll}
\hline Categori & \multicolumn{1}{c}{ Indicator } \\
\hline Check & 1. Students find problems encountered \\
& 2. Students have a solution \\
\hline Criticize & 1. Define the problems found in accordance with the scope of performance \\
& 2. Finding a settlement procedure that suits the scope of performance \\
\hline
\end{tabular}

Data analysis techniques to determine the ability of student evaluations in the application of the TAI learning model are processed by accumulating total scores. The results of the accumulation of scores are searched for an average score per indicator of evaluation ability and standard deviation. The score is used to rank the ability of evaluation of physics education students in the implementation of school assistance. The criteria for grouping the ability to evaluate the implementation of school assistance are presented in bold below.

The category table evaluates the ability of student evaluations in the implementation of school assistance [17] as follows.

Table 2. Evaluation Ability Score Categories

\begin{tabular}{ccc}
\hline No. & Score Range & Category \\
\hline 1. & $\mathrm{X} \geq \bar{X}+\mathrm{SD}$ & High \\
2. & $\bar{X}-\mathrm{SD} \leq \mathrm{X}<\bar{X}+\mathrm{SD}$ & Medium \\
3. & $\mathrm{X}<\bar{X}-\mathrm{SD}$ & Low \\
\hline
\end{tabular}


Infromation:

$X=$ Student/team evaluation ability score

$\bar{X}=$ Average score of evaluation ability of all students / teams

$\mathrm{SD}=$ Standard deviation or standard deviation of all students' ability to evaluate scores

Implementation of physics assistance learning consists of four teams with each team consisting of five students. Physics assistance learning was carried out in four high schools in PurworejoDistrict, SMA Islam Sudirman Bruno, SMA N 9 Purworejo, SMA N 11 Purworejo, and SMA N 5 Purworejo. Physics assistance learning is carried out in the respective school laboratories for the XI MIPA class. The steps of implementing physics assistance learning using the TAI learning model according to as follows [2]:

a. Teams, that is the stage of forming a team of five students. The team was formed into four teams for four high schools in Purworejo District,

b. Placement test, team formation procedure with each team consisting of five students based on the interest in physics material to be practiced,

c. Teaching group, each team made a team work program by carrying out preliminary studies and observations to each of the targeted schools,

d. Student creative, each team makes and designs learning tools to prepare for the implementation of physics assistance in schools. The tools prepared include physics learning media, practicum modules, and evaluation tools in the form of tests. The learning tools prepared are adjusted to the needs analysis of each school. Evaluation tools in the form of pre-test and post-test are validated by the supervisor.

The TAI learning model has four stages of implementation, first, Teams is the stage of forming a team consisting of 4 teams, each consisting of 5 to 6 students.

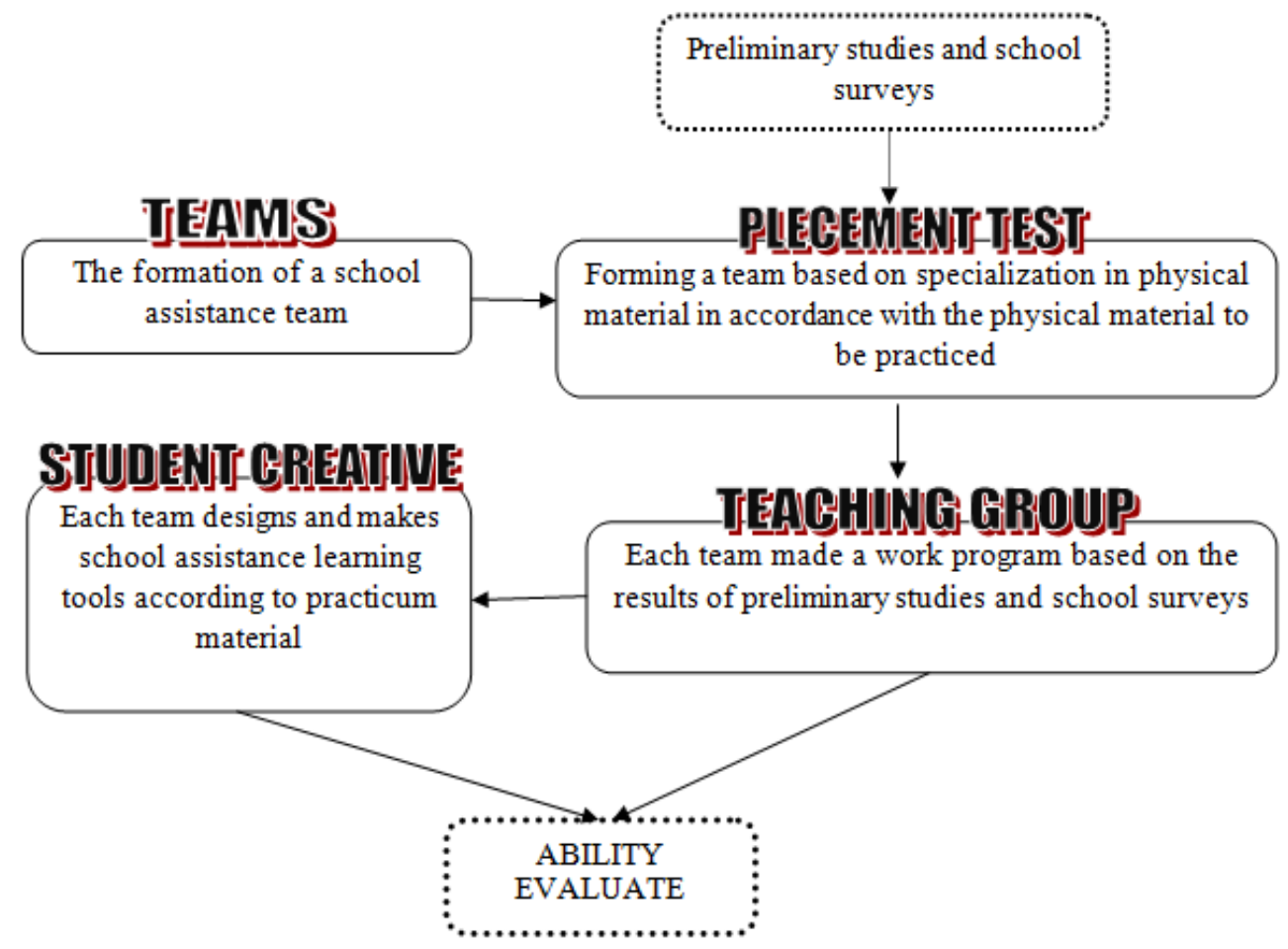

Fig 1. Flowchart of TAI Learning Model School Assistance Implementation

\section{RESULTS AND DISCUSSIONS}

Activities that have been carried out in this study with the implementation of school assistance are teaching practice courses in partner schools by becoming a mentor or assistant teacher in the 
implementation of physics practicum in partner schools. This activity is by applying the TAI learning model to find out the ability to evaluate students in the process of implementing school assistance. TAI learning model can improve student learning outcomes can also be applied to students in school assistance activities [19]. The flow of stages of the TAI learning model can be seen in the diagram below. Evaluation of students' evaluation skills is assessed at each stage of the TAI learning model by originating in a hardcopy report on school assistance and a report in the form of a presentation on the implementation of school assistance.The final test on the presentation of the report on the implementation of school assistance was conducted a question and answer process and interviews with the implementation team.

Second, the Placement Test is a continuation of the stage of team formation in accordance with the specialization of the material. Physics material that is practiced is temperature and calor, Hook law, and Ohm law. In this second phase each team conducted a preliminary study and survey of partner schools. There are 4 partner schools for each team can be seen in the table below.

Table 3. School Assistance Team Description

\begin{tabular}{|c|c|c|c|c|}
\hline No & Team & Amount of Members & Physics Material & Partner School \\
\hline 1 & A & 6 students & Temperature and Calor & $\begin{array}{c}\text { State Vocational High School } 7 \\
\text { of Purworejo }\end{array}$ \\
\hline 2 & B & 5 students & Ohm Law & $\begin{array}{c}\text { State Vocational High School } 8 \\
\text { of Purworejo }\end{array}$ \\
\hline 3 & $\mathrm{C}$ & 5 students & Hook Law & $\begin{array}{l}\text { State Senior High of Purworejo } \\
\text { School } 3 \text { of Purworejo }\end{array}$ \\
\hline 4 & D & 5 students & Hook Law & $\begin{array}{c}\text { State Vocational High School } 4 \\
\text { of Purworejo }\end{array}$ \\
\hline \multicolumn{2}{|c|}{ Amount } & 21 students & & \\
\hline
\end{tabular}

The second stage of the TAI learning model is the plecementtest, at this stage students consisting of four teams conduct preliminary studies and school surveys. The results of the preliminary study and the fourteam school survey can be seen from Table 4 below. In the third stage of the Teaching Group and the fourth stage of Student Creative is the evaluation stage of the ability to evaluate. The third stage is the stage of preparing a work program based on preliminary studies and survey of partner schools. The fourth stage students design and make school assistance learning tools according to practicum material from the results of the third stage.

Table 4 Preliminary Study Results Team A and Team B

\begin{tabular}{|c|c|c|c|c|}
\hline No & Team & $\begin{array}{l}\text { Results of Preliminary Study and } \\
\text { School Survey }\end{array}$ & Information & Target \\
\hline 1 . & A & $\begin{array}{l}\text { 1. School distance from UMP campus is } \\
\text { more than } 12 \mathrm{~km} \\
\text { 2. The number of class X students is } 72 \\
\text { students } \\
\text { 3. Rarely do physics practicum } \\
\text { 4. Laboratory equipment is not } \\
\text { functioning optimally }\end{array}$ & $\begin{array}{l}\text { Data obtained in accordance } \\
\text { with the objectives and } \\
\text { scope of school assistance }\end{array}$ & $80 \%$ \\
\hline & B & $\begin{array}{l}\text { 1. Information on physics subject } \\
\text { schedules as a basis for practicum } \\
\text { implementation } \\
\text { 2. No physical material has been } \\
\text { practiced yet } \\
\text { 3. Based on the lab equipment data there } \\
\text { are many laboratory equipment that is } \\
\text { damaged }\end{array}$ & $\begin{array}{l}\text { Data obtained in accordance } \\
\text { with the objectives and } \\
\text { scope of school assistance }\end{array}$ & $70 \%$ \\
\hline
\end{tabular}


Table 4 above shows that Team A and Team B obtained survey information to the school in preparation for the initial implementation of school assistance. Two important information on the implementation of school assistance is information on the use of laboratories and tools available at partner schools. This affects the design of work programs, especially the preparation of practical tools. Table 5 below shows the results of the preliminary study of Team $\mathrm{C}$ and Team D. Team D shows the results of a preliminary study from a survey of partner schools with the same results as TIM A, while Team C obtained the results of a preliminary study far from the scope of school assistance work. Team C just does not focus on the data or information needed as a process of designing work programs, so the results of the report on the implementation of school assistance shows that the basis of the implementation of school assistance team $\mathrm{C}$ lacks valid information.

Table 5. Preliminary Study Results Team C and Team D

\begin{tabular}{|c|c|c|c|c|}
\hline No & Team & $\begin{array}{l}\text { Results of Preliminary Study } \\
\text { and School Survey }\end{array}$ & Information & Target \\
\hline 1. & $\mathrm{C}$ & $\begin{array}{l}\text { 1. Strategic school facilities } \\
\text { 2. Schools that pay great } \\
\text { attention to traditional art. } \\
\text { This can be seen from the } \\
\text { extracurricular associated } \\
\text { with the arts }\end{array}$ & $\begin{array}{l}\text { The data obtained were not all } \\
\text { compatible with the school } \\
\text { environment and environmental } \\
\text { attitudes }\end{array}$ & $60 \%$ \\
\hline 2. & $\mathrm{D}$ & $\begin{array}{l}\text { 1. Class X physics subject } \\
\text { schedule } \\
\text { 2. Material data that has not } \\
\text { been and has been } \\
\text { practiced } \\
\text { 3. Data on the state of school } \\
\text { 4. Physical physics practices } \\
\text { are rarely carried out }\end{array}$ & $\begin{array}{l}\text { The data obtained are in accordance } \\
\text { with the goals and environment of } \\
\text { the school environment }\end{array}$ & $80 \%$ \\
\hline
\end{tabular}

The results of the preliminary study in Table 3 and Table 4 above will determine the third stage of the teaching group and the fourth stage of student creative. This stage is the design phase of the work program based on preliminary studies and manufacturing of devices based on the third stage. The following is a work program design based on the school assistance report for each team, which can be seen in the graph below.

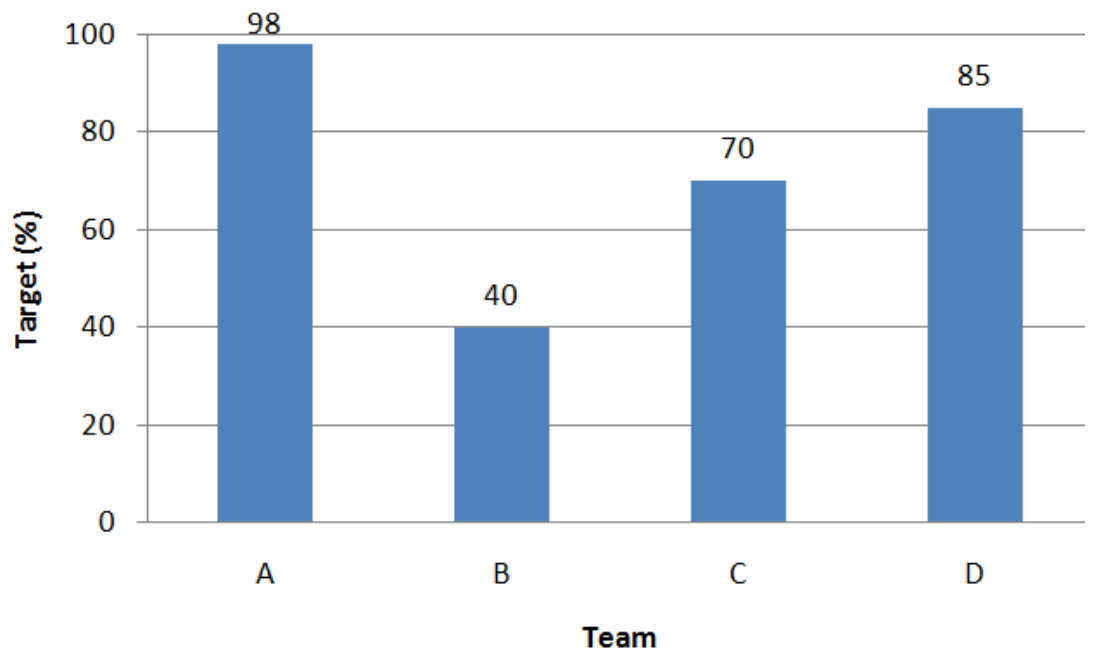

Fig 2. Achievement Charts for Each Team's Work Program Target at the Analyze Student Stage

Based on the program design for each team in the graph above it can be seen that only team A provides a complete design according to the assignment target of $98 \%$. Team A provides a complete and 
sequential explanation, especially in the evaluation evaluation design and process skills assessment indicators. Whereas the $\mathrm{C}$ and $\mathrm{D}$ teams gave an incomplete work program design report especially the evaluation evaluation design. Team D drafted $40 \%$ of the total assignment target but was incomplete in observing students' process skills. Team D did not include the design of the practicum module and also the design of the implementation of school assistance, so team D did not meet the target scope of the implementation of school assistance.Based on reporting in stages one through stage four, the analysis of the preliminary study and the solutions provided by each team were produced. Study analyzes are listed in the table below [20].

Table 6. Evaluation of Preliminary Studies and Solutions for Implementing School Assistance for Team A and Team B

\begin{tabular}{|c|c|c|c|c|}
\hline No & Team & $\begin{array}{l}\text { Problems with implementing } \\
\text { School Assistants }\end{array}$ & The solution & Target \\
\hline 1. & A & $\begin{array}{l}\text { 1. Students have difficulty in } \\
\text { making reports } \\
\text { 2. Lack of Coordination with the } \\
\text { school } \\
\text { 3. Students' ability in carrying } \\
\text { out practicum is not good, } \\
\text { because they rarely carry out } \\
\text { practicum }\end{array}$ & $\begin{array}{l}\text { 1. Conducting } \\
\text { temperature } \\
\text { material }\end{array}$ & $30 \%$ \\
\hline 2. & B & $\begin{array}{l}\text { 1. Inadequate availability of } \\
\text { tools, } \\
\text { 2. Accuracy of measuring } \\
\text { accuracy (observer error in } \\
\text { reading mass measurements } \\
\text { using a balance sheet) } \\
\text { 3. Most students have difficulty } \\
\text { in converting units of voltage } \\
\text { and current } \\
\text { 4. Paractic devices are not } \\
\text { calibrated }\end{array}$ & $\begin{array}{l}\text { 1. Using campus alternative } \\
\text { practicum tools } \\
\text { 2. Students make teaching media } \\
\text { in accordance with practicum } \\
\text { material } \\
\text { 3. Provision of briefing and } \\
\text { explanation in detail before the } \\
\text { practicum } \\
\text { 4. Provision of practical material } \\
\text { theory }\end{array}$ & $60 \%$ \\
\hline
\end{tabular}

Based on the data obtained that Team A reached the target of 30\%, this is because there is a mismatch between the problem at hand and the solution provided. Team A did not explore the solutions found when implementing school assistance. Team B found problems relating to the implementation of the practicum, specifically unit conversion and how to use measurement tools correctly, but the solutions provided did not answer the obstacles faced by students, this was due to time constraints and the limited available parktikum tools. In contrast to Team $\mathrm{D}$, the solutions provided did not solve the problem at hand. This team highlights the many face-to-face and performance that is not in accordance with the burden of recovery. Team D actually discussed problems that were less related to the implementation of school assistance, they assumed the workload of implementing school assistance was not in accordance with the burden of the semester credit system (SKS) that was already listed in the Physics Education Study Program curriculum. School assistance courses are listed with a 2 SKS, but the real workload in the field exceeds the 2 SKS workload, such as starting from a survey of partner schools with several meetings, the results of the survey will be the result of a preliminary study, followed by reviewing the work program with the agenda of preparing the practical module, compiling evaluation evaluation, and design of practicum implementation according to predetermined physics material. Team $\mathrm{C}$ is the team that received the highest score of $85 \%$ for the analysis of preliminary studies and solutions, since Team $\mathrm{C}$ provided a good preliminary study and the suitability of the constraints with the solution provided [21]. Constraints in calculating the inaccuracy of the swing time calculation are overcome by taking data starting with conditioning the pendulum swing completely in a stationary and balanced condition. This Team $\mathrm{C}$ provides a solution to the constraints faced physically according to the theme of the mathematical pendulum swing practicum in determining gravity velocity, this Team $\mathrm{C}$ provides the right solution in overcoming the problems that often arise in the mathematical pendulum practicum theme. 
The results of this implementation are in line with research [22] that the TAI learning model can increase student activity in the implementation of learning and student learning outcomes. [Following are the results of the preliminary study achievements and the solutions provided for Team C and Team D.

Table 7. Evaluation of Preliminary Studies and Solutions for Implementing School Assistance for Team C and Team D

\begin{tabular}{|c|c|c|c|c|}
\hline No & Team & $\begin{array}{c}\text { Problems with implementing } \\
\text { School Assistants }\end{array}$ & The Solution & Target \\
\hline 1. & $\mathrm{C}$ & $\begin{array}{l}\text { 1. Practicum constraints such } \\
\text { as: The initial position of the } \\
\text { spring is not in a state of } \\
\text { balance } \\
\text { 2. The timer timer is not correct } \\
\text { when the start and end times } \\
\text { 3. The height of the pendulum } \\
\text { swing is less effective } \\
\text { 4. The atmosphere of the } \\
\text { practicum is not conducive } \\
\text { because it is carried out in the } \\
\text { classroom. }\end{array}$ & $\begin{array}{l}\text { 1. Calculation of the addition of the } \\
\text { mass of the load by recalculation } \\
\text { and springs in balance conditions } \\
\text { 2. Measuring the length increase for } \\
\text { the strain, the spring must be at } \\
\text { rest } \\
\text { 3. Students focus when calculating } \\
\text { vibration and the accuracy of time } \\
\text { calculations } \\
\text { 4. The swing rope length is adjusted } \\
\text { to the swing platform to facilitate } \\
\text { the vibration calculation process }\end{array}$ & $85 \%$ \\
\hline 2. & $\mathrm{D}$ & $\begin{array}{l}\text { 1. Lack of good communication } \\
\text { with partner schools } \\
\text { 2. The classroom atmosphere is } \\
\text { not conducive because of the } \\
\text { lack of focus of students in } \\
\text { carrying out practical work }\end{array}$ & $\begin{array}{l}\text { 1. The implementation of school } \\
\text { assistance requires very } \\
\text { thorough preparation from the } \\
\text { preparation of preliminary } \\
\text { studies, school surveys, the } \\
\text { design of practicum tools and } \\
\text { preparation for practicum } \\
\text { implementation, especially the } \\
\text { implementation of practicum } \\
\text { that requires more than six face- } \\
\text { to-face meetings so that the eyes } \\
\text { of the college should get a } 2 \text { SKS } \\
\text { burden. }\end{array}$ & $50 \%$ \\
\hline
\end{tabular}

Based on the description of the stages of learning TAI from stage 1 to stage 4 provides an assessment of the ability to examine and criticize for 4 teams or evaluation abilities as follows [23].

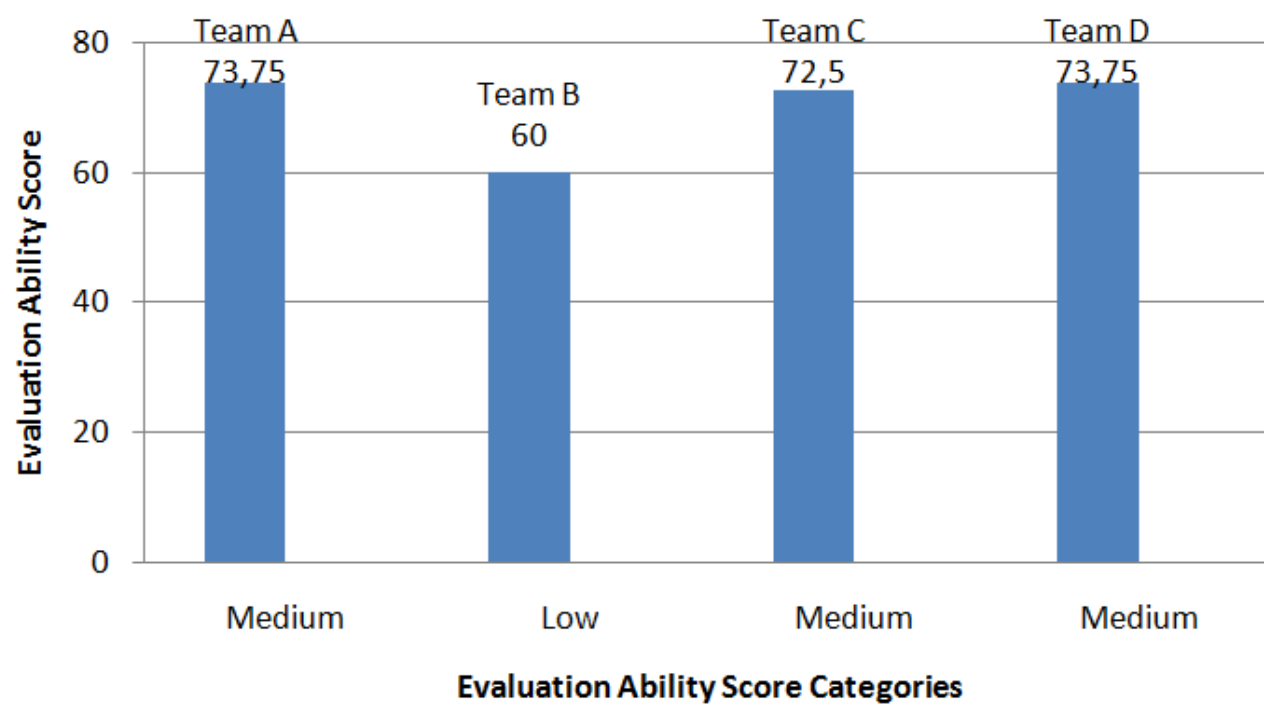

Fig 3. Evaluation Capability Chart for Team A, Team B, Team C and Team D 
The evaluation ability of each team produces medium category ability for Team A, C, and D. While Team B produces low evaluation ability, because in the initial stages of the test plecement does not produce representative data and does not fit the scope of the implementation of school assistance. In addition, Team B made a solution by not considering the findings of the preliminary study data in the field. Team B has low evaluation capability, especially on the 3rd indicator, which is the problem obtained is not in accordance with the problem of the scope of the implementation of school assistance so that this has an impact with the solutions made [8]. Practicum problems faced by partner schools in Team B do not have adequate practicum tools in accordance with the practicum themes carried out, Team B only uses practicum tools available without making appropriate solutions for example by making alternative practicum tools themselves. Besides that the practicum guidance module and evaluation design are not listed in the school assistance report, this is not in line with the implementation of the school assistance grid, because these two things are very important as a process of monitoring and evaluating the implementation of school assistance. Teams A, C, and D produce the evaluation abilities of medium category students. Each team produced a score of 73.75; 72.5 and Team D has a score of 73.75. These results are commensurate with the application of the TAI learning model that can affect the process of solving physics learning [24-25] and can be applied to school assistance for physics practicum. With this model TAI learning can improve student learning outcomes [26].

\section{CONCLUSION}

The application of the TAI model in school assistance learning has an important role in growing students' skills in working in teams and learning together to solve problems in teams. The implementation of school assistance for four teams with four partner schools resulted in the best evaluation ability in the second indicator of $77.50 \%$, the ability to provide a general solution to the results of the preliminary study for preliminary data. While the results of the lowest evaluation ability on the 4th indicator were $56.25 \%$, namely the ability to find completion procedures that fit the scope of performance and the target of implementing school assistance. In general, the evaluation skills of Team A and Team D received a moderate category with a score of $73.75 \%$ and Team B received a category of low evaluation ability score of $60 \%$.

\section{REFERENCES}

[1] Saregar, A., Diani, R., \& Kholid, R. (2017). Efektivitas penerapan model pembelajaran ATI (Aptitude Treatment Interaction) dan model pembelajaran TAI (Team Assisted Individualy): dampak terhadap hasil belajar fisika siswa. Jurnal Pendidikan Fisika Dan Keilmuan (JPFK), 3(1): 28-35.

[2] Ariani, T. (2017). Pembelajaran Kooperatif Tipe Team Assisted Individualization (TAI): Dampak Terhadap Hasil Belajar Fisika Siswa. Jurnal Ilmiah Pendidikan Fisika Al-BiRuNi, 6(2): 169-177.

[3] Aryani, S., Apriani, H., \& Akhyar, O. (2018). Pengaruh Penerapan Peer Assesment Melalui Model Team Assisted Individualzation (TAI) Pada Materi Kelarutan Dan Hasil Kali Kelarutan Terhadap Hasil Belajar Siswa Di SMAN 9 Banjarmasin. Dalton: Jurnal Pendidikan Kimia dan Ilmu Kimia, l(2).

[4] Komalasari, R. D., Rufaidah, E., \& Rusman, T. (2018). Perbandingan Soft Skill Model Pembelajaran GI Dan TAI Dengan Memperhatikan Keterampilan Sosial. JEE (Jurnal Edukasi Ekobis), 6(7).

[5] Hidayat, H., Herawati, S., Hidayati, A., \& Syahmaidi, E. (2018, March). Pembelajaran Kewirausahaan dengan pendekatan berbasis produksi sebagai alternatif mempersiapkan lulusan berkualitas di pendidikan tinggi. In Prosiding Seminar Nasional Pakar (pp. 123-129).

[6] Maghfiroh, U. (2011). Penerapan Pembelajaran Fisika Bervisi SETS untuk Meningkatkan Kemampuan Berpikir Analitis Peserta Didik Kelas X. Jurnal Pendidikan Fisika Indonesia, 7(1).

[7] Anwar, A., \& Santosa, R. H. (2019). Efektivitas Model Pembelajaran Tipe Team Assisted 
Individualization (TAI) Ditinjau Dari Prestasi Belajar Dan Self-Efficacy Matematika Siswa SMP. AKSIOMA: Jurnal Program Studi Pendidikan Matematika, 8(1): 49-57.

[8] Gumrowi, A. (2016). Meningkatkan hasil belajar listrik dinamik menggunakan strategi pembelajaran team assisted individualization melalui simulasi crocodile physics. Jurnal Ilmiah Pendidikan Fisika Al-Biruni, 5(1): 105-111.

[9] Perdana, A., Siswoyo, S., \& Sunaryo, S. (2017). Pengembangan Lembar Kerja Siswa berbasis Discovery Learning Berbantuan Phet Interactive Simulations Pada Materi Hukum Newton. WaPFi (Wahana Pendidikan Fisika), 2(1).

[10] Sari, H. K. (2016). Peningkatan Keterampilan Proses Sains dan Hasil Belajar Fisika Siswa pada Model Pembelajaran Kooperatif Tipe Student Team Achievement Division. Tadris: Jurnal Keguruan Dan Ilmu Tarbiyah, 1(1): 15-22.

[11] Park, C. (2004). The graduate teaching assistant (GTA): Lessons from North American experience. Teaching in Higher Education, 9(3): 349-361.

[12] Wilson, L. O. (2016). Anderson and Krathwohl-Bloom's Taxonomy Revised: Understanding the New Version of Bloom's Taxonomy.

[13] Wattimena, H. S., Suhandi, A., \& Setiawan, A. (2014). Profil Penyelenggaraan Praktikum Fisika Sekolah sebagai Penyiapan Mengembangkan Kreativitas Calon Guru. Jurnal Pendidikan MIPA (Old), 15(2).

[14] Wardoyo, S. M. (2013). Pembelajaran Konstruktivisme Teori dan Aplikasi Pembelajaran dalam Pembentukan Karakter. Bandung: Alfabeta.

[15] Susanti, W., \& Jatmiko, B. (2016). Implementasi model pembelajaran kooperatif tipe TAI (team assisted individualization) untuk meningkatkan hasil belajar fisika siswa SMA pada materi elastisitas. Jurnal Penelitian Fisika dan Aplikasinya (JPFA), 6(1): 26-33.

[16] Emzir. (2009). Metodologi Penelitian Pendidikan Kualitatif dan Kuantitatif. Jakarta: PT Raja Grafindo Pergoda.

[17] Sugiyono. (2012). Metode Penelitian Kuantitatif, Kualitatif, dan R\&D. Bandung: Alfabeta.

[18] Arikunto. (2008). Dasar-Dasar Evaluasi Pendidikan. Jakarta: BumiAksara.

[19] Is, I. I. I. (2018). Penerapan Model Pembelajaran Kooperatif TAI (Team Assisted Individualization) Untuk Meningkatkan Hasil Belajar Fisika Pada Materi Pokok Pesawat Sederhana. Jurnal Serambi Ilmu, 18(2).

[20] Madsen, A., McKagan, S. B., \& Sayre, E. C. (2015). How physics instruction impacts students' beliefs about learning physics: A meta-analysis of 24 studies. Physical Review Special TopicsPhysics Education Research, 11(1): 010115.

[21] Desiana, N., Elisa, \& Zainul, A.I.S. (2018). The Implementation of Team Assisted Individuaization (TAI) Type Cooperative Model To Increase learning Outcomes in Work Energy. Inovasi Pendidikan Fisika, 7(2).

[22] Fitriyah, A. (2017). Penerapan model pembelajaran kooperatif tipe TAI (Team Assisted Individualization) untuk meningkatkan aktivitas dan hasil belajar siswa kelas x pada pokok bahasan momentum dan impuls di MAN Mojosari Mojokerto. Inovasi Pendidikan Fisika, 6(3).

[23] Komalasari, R. D., Rufaidah, E., \& Rusman, T. (2018). Perbandingan Soft Skill Model Pembelajaran GI Dan TAI Dengan Memperhatikan Keterampilan Sosial. JEE (Jurnal Edukasi Ekobis), 6(7).

[24] Iklima, I., Marzal, J., \& Damris, M. (2016). Pengaruh Model Pembelajaran Kooperatif Tipe Team Assisted Individualization dan Self-Efficacy terhadap Kemampuan Pemecahan Masalah Fisika Siswa di MTs N Kota Jambi. Edu-Sains: Jurnal Pendidikan Matematika dan Ilmu Pengetahuan Alam Universitas Jember, 5(1): 58734.

[25] Kasriani, K. (2018). Perbandingan Hasil Belajar Fisika Melalui Metode Pembelajaran (STAD dan TAI) Berbasis Praktikum Pada Kelas XI IPA Dengan Memperhatikan (EQ) Emotional Quotient siswa MA As' Adiyah Putri Pusat Sengkang (Doctoral dissertation, Universitas Islam Negeri Alauddin Makassar).

[26] Ariani, T. (2017). Pembelajaran Kooperatif Tipe Team Assisted Individualization (TAI): Dampak Terhadap Hasil Belajar Fisika Siswa. Jurnal Ilmiah Pendidikan Fisika Al-BiRuNi, 6(2): 169-177. 